\title{
The Balkan Mountains Paleozoic gold deposits
}

\author{
Mladenova V. ${ }^{1}$, Kerestedjian T. ${ }^{2}$ and Dimitrova D. ${ }^{2}$ \\ ${ }^{1}$ Sofia University "St. KI. Ohridski", Department of Mineralogy, Petrology and Economic Geology, \\ BG-1504 Sofia, vassilka ஹg gea.uni-sofia.bg
}
2 Geological Institute of BAS, BG-1113 Sofia, Bulgaria, thomas@geology.bas.bg, didi@geology.bas.bg

\section{ABSTRACT}

A number of Paleozoic gold deposits are situated in the Hercynian terrains of the Balkan Mountain. On Bulgarian territory Govezhda and Svishti Plaz deposits are the most important ones. Neresnitza, Blagoev-Ka nen and Osanitza deposits are located in the Serbian part of the Balkan Mountain.

All these deposits are hosted in the Pre-Alpine basement of the Balkanide zone. The orehosting structures are veins, lenses and mineralized fissures related to tension and shear faults. The structural characteristics of the ores are an evidence for tectonic control and tectonic activity during the ore deposition. All stages of ore deposition were accompanied by strong fracturing of already deposited minerals and subsequent precipitation of next portion.

The economically important mineral in all these deposits is the native gold, with variable $\mathrm{Ag}$ contents. In the two Bulgarian deposits the main ore minerals are arsenopyrite and pyrite. Arsenopyrite is not reported for Serbiın deposits, but scheelite is a main mineral there instead.

Based on mineral associations, three possible genetic concepts of Au deposition could be expressed. 1) The gold is genetically associated with arsenopyrite and pyrite from stage 1 (Fe-As$\mathrm{Au} \pm \mathrm{W}$ ). It is primarily deposited as invisible gold in these minerals. During the next stage of sulfide deposition driven by induced heating, it is remobilized and redeposited in cracks, formed during the cataclastic events of this stage. 2) The gold is genetically connected to the stage 2 ( $\mathrm{Pb}-\mathrm{Zn}-\mathrm{Cu}-\mathrm{Ag}$ Au). 3) Dual generation of gold related to both stages 1 and 2 .

All Balkan Paleozoic gold deposits show lots of similarities to mesothermal gold deposits in shear zones in Archaean greenschists terrains in Canada, Western Australia and Africa, as well as to Hercynian gold depos its in France and Portugal. The similarity especially concerns their connection to granodioritic magmatism, the mineral parageneses and the gold occurrence and its associations.

Despite that the mining in the Balkan gold deposits is already closed, they still have nonexplored and non-operated reserves.

\section{INTRODUCTION}

The gold deposits in Archaean greenschist terrains are one of the most important gold concentrators in the world. Sorne deposits from the same type are concentrated in Hercynian terrains in Europe in France and Portugal.

A number of Paleozoic gold deposits are situated in the Hercynian terrains of the Balkan Niountain on Bulgarian as well on Serbian territory (Fig. 1).

Two big deposits are known in the Bulgarian part. The big ancient vast dumps and mine workings are evidences for the extraction activity in far and recent past.

The Govezhda deposit is located close to the border between Bulgaria and Serbia and is exploited in the 1961-1992 period. The gold contents in the ore vary from 1.0 to $8.3 \mathrm{ppm}$, and the silver content - from few to 30-35 ppm. The deposit has produced 1105,6 thousand tons of ore with average Au content of $3.5 \mathrm{ppm}$ and $3863 \mathrm{~kg}$ pure gold (Milev et al. 1996). It is closed because of 
strong environmental and economical problems despite the fact that the deposit still has unexploited reserves of gold ore (Kalaidjiev et al. 1989).

The Svishti Plaz depos : is situated at an altitude of about $1500 \mathrm{~m}$ in the Zlatitza part of Balkan Mountain. The deposit is prospected during 1964-1979. As a result, dozens of base metal-goldquartz ore veins with average contents of $\mathrm{Au}$ of $6.6 \mathrm{ppm}, \mathrm{Ag}$ of $16.6 \mathrm{ppm}$ and $\mathrm{Pb}$ of $0.62 \%$ are established (Parvanov \& Mateev 1980), but unfortunately their sizes were assessed as insufficient. The deposit has never been operating because of the high altitude and the high As content in the ores too. Several smaller gold deposits in the region are only prospected.

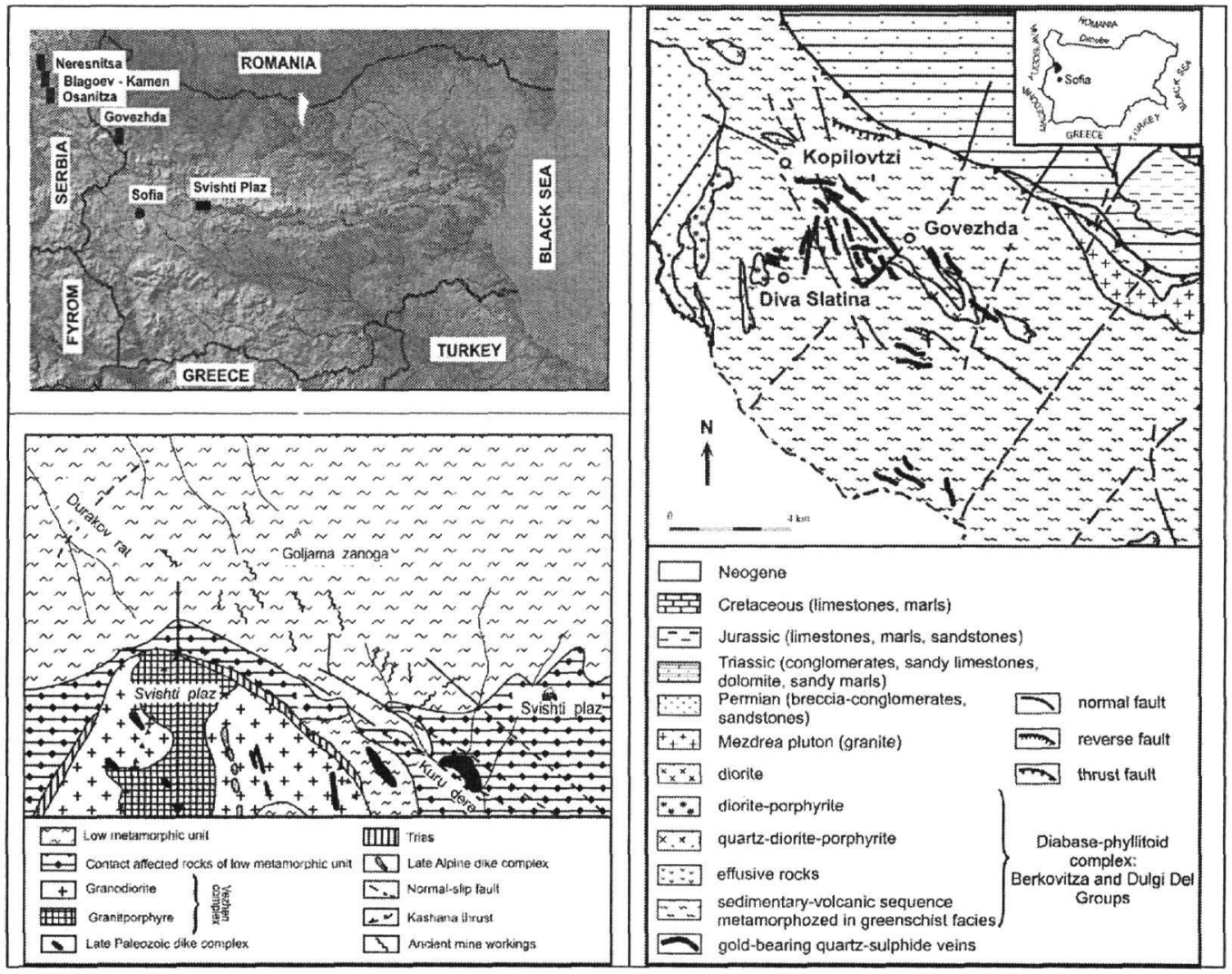

Figure 1. Location of the Paleozoic gold deposits in the frame of the Balkan Mountain and geological settings of the Bulgarian gold deposits Govezhda (after Petrov 1981) and Svishti Plaz (after Kujkin et al. 1972)

The Neresnitza, Blagoev-Kamen and Osanitza deposits are located in the Serbian part of the Balkan Mountain and belong to the East-Serbian metallogenic region. The last two of them are mostly considered as tungsten deposits because of the scheelite as a main mineral. The gold in Neresnitza deposit varies from 3-12 to $40 \mathrm{ppm}$. The deposit was closed in 1954. Blagoev-Kamen was in operation for gold and tungsten until 1963 and Osanitza deposit was never operated (Jankovic, 1982).

All gold deposits belong to the bigger metallogenic belt along the Balkan Mountain, which hosts a lot of deposits of the same age and similar genesis. Beside the $\mathrm{Au}$, mineralization of $\mathrm{Ag}, \mathrm{Pb}, \mathrm{Fe}$, $\mathrm{Cu}, \mathrm{FeS}_{2}, \mathrm{TR}, \mathrm{Mo}, \mathrm{W}, \mathrm{Bi}$, barite, fluorite occur in this belt. 


\section{GEOLOGICAL SETTING}

The Balkan Paleozoic gold deposits are hosted in the Pre-Alpine basement of the Balkanide zone. It is made up of various sedimentary rocks and diabasic magmatic bodies all they metamorphosed by regional metamorphism under greenschists facies conditions during the Lower Carboniferous. After the metamorphic events in the complex were intruded magmatic bodies with granite to granodiorite compositior which compositions, structural characteristics and positions point to epi- to mesozonal products of core magmatic source (Ivanov et al., 1987). Haydoutov (1991) on the base of isotopic ratio $\mathrm{Sr}^{87} / \mathrm{Sr}^{86}$ concludes that the Hercynian granitoids in the Balkan Mountain are postcollision calc-alkaline l-type and that the magma was generated in the lower parts of the crust or in the mantle. The situation of magmatic bodies in elongated zone in the Pre-Mesozoic complex in Balkan Mountain (in Bulgaria and Serbia), South Carpathians (Rumania) suggest their connection with the regional tectonic situation characteristic of linear elongated frontal arcs (Ivanov, 2002; Ivanov et al., 1987). The contact zones of metamorphic rocks are transformed in hornfelses, porphyroblastic schists and amphibolites. A genetic connection of gold deposits with the Hercynian granitoide intrusions anc related dykes is believed (Kuikin et al. 1972).

During Permian-Lower Triassic, Middle Triassic, Lower Jurassic and Quaternary periods are deposited sediments as conglomerates, sandstones and limestones (Nikolaev, Tonev, 1961; Kujkin, Milanov, 1970).

Figure 1 represents the geological settings of the Bulgarian gold deposits Govezhda and Svishti Plaz and the location of the Serbian deposits in the frame of the Balkan Mountain.

\section{ORE STRUCTURES}

The vein type mineralizations are hosted in the Paleozoic low-crystalline schists, dioritic, granodioritic and quartz-dioritic plutonic bodies and related hornfelses. The ore-hosting structures are veins, lenses, metasomatic bodies and mineralized fissures related to tension and shear faults. Some ore veins are situated in the contact zones of the dikes. The structural characteristics of the ore are an evidence for tectonic control and tectonic activity during the ore deposition. All stages of ore deposition were accompanied by strong fracturing of already deposited minerals and subsequent precipitation of next portion.

More than 30 ore veins, striking $150-160^{\circ}$ and $175-180^{\circ} \mathrm{SE}, 0-10^{\circ} \mathrm{NNE}$ and $65-70^{\circ} \mathrm{ENE}$ and dipping $60-90^{\circ} \mathrm{SW}$ with length around $100-350 \mathrm{~m}$ (some of them up to $1 \mathrm{~km}$ ) and thickness from 0.20 to $2.5 \mathrm{~m}$ were explured in Svishti Plaz deposit (Kuikin et al., 1972).

In Govezhda deposit the veins strike $270-320^{\circ} \mathrm{SW}$ and dip $30-70^{\circ} \mathrm{NW}$. The vein lengths vary from few to $600 \mathrm{~m}$ and thicknesses from several $\mathrm{cm}$ to 5-6 $\mathrm{m}$ (Nikolaev, Tonev, 1961).

The thickness of vein-related wall-rock alteration is proportional to vein thickness and bleaches the rocks up to a few meters from the veins. Alteration is characterized by silicification, sericitization of plagioclase, kaolinitization of potassium feldspar and chloritization of biotite.

\section{MINERAL ASSOCIATIONS}

The hydrothermal mıneralization of the Bulgarian deposits can be divided into five paragenetic stages, based on crosscutting relations and electron-microprobe analyses.

Stage 1 (Fe-As-Au+W) in both deposits has simple mineral composition and consists mainly of pyrite, arsenopyrite and gray quartz. The minerals from this stage have undergone strong brittle deformation.

Arsenopyrite and pyrite are the dominant ore minerals in both deposits, for both the stage and the whole mineralization. Single crystals of these mineral are found dispersed in the host rocks or are concentrated in groups and aggregates of numerous intergrown individuals in veins. The relationships between them suggest co-precipitation, although in some samples pyrite is obviously earlier. Almost always they are strongly fractured and late galena, tennantite, sphalerite, chalcopyrite and gold infill their fractures (Fig. 2A, 3A).

Pyrrhotite is found as $5-10 \mu \mathrm{m}$ oval inclusions in pyrite I. Partial to complete replacement of pyrrhotite by marcasite and/or pyrite is common. 
Gold $l$ is associated with the Fe-sulfides from this stage (Fig. 3A).

Scheelite is established only in Govezhda deposit.

Stage $2(P b-\mathrm{Zn}-\mathrm{Cu}-\mathrm{Ag}-\mathrm{Au})$ is the main Au-Ag-base metal stage. It is characterized mainly by sphalerite, galena, chalcopyrite, gold and fahl ore intergrown with gray quartz.

Sphalerite and galena are the principle minerals of the second stages. They are deposited as massive aggregates, irregular grains or veinlets in quartz or fill fissures in earlier pyrite and arsenopyrite (Fig. 2A, 2B, 3B). Galena is very pure, without inclusions and only contains insignificant
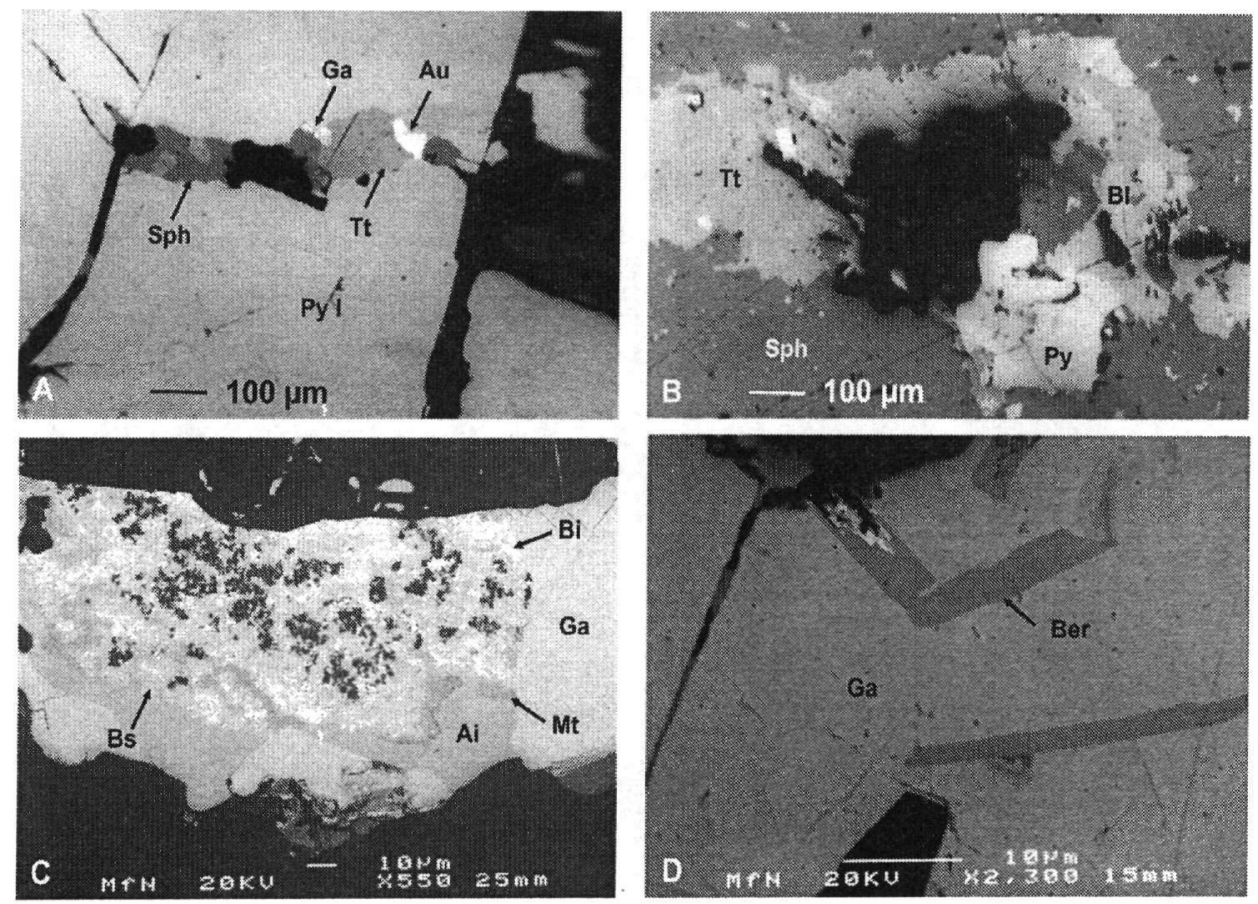

Figure 2. Photomicrographs of mineral assemblages of the different stages. $\mathbf{A}$ - Native gold ( $\mathrm{Au})$, galena (Ga), sphalerite $(\mathrm{Sph})$ and tetrahedrite $(\mathrm{Tt})$ infilling fractures in strongly cataclased pyritel (Py) from (Fe-As-AutW) stage, Sample Govezhda g3/7; B - Tetrahedrite ( $\mathrm{Tt}$ ) and boulangerite $(\mathrm{BI})$ from stage $3(\mathrm{Ag}-\mathrm{Pb}-\mathrm{Cu}-\mathrm{Sb})$ fill micro-fractures in sphalerite (Sph) and pyrite (Py), Sample Govezhda 610/5, C - Myrmekite-like intergrowths of complex bismuth minerals and galena after pyrite (dark mineral), SEM, BSE; Ai - aikinite-friedrichite, Bi- native bismuth, Bs- bismuthinite-pekoite, Ga-galena, Mt - $\mathrm{Ag}(\mathrm{Pb})$-Bi sulfosalts (matildite?), Sample Svishti Plaz 7G/1, D - Bismuthiferous galena $(\mathrm{Ga})$ containing longprismatic inclusions of berryite (Ber) or benjaminite(?), SEM, BSE, Sample Svishti Plaz 7G/1

quantities of $\mathrm{Cu}$. Sphalerite forms irregular grains and contains lots of inclusions of chalcopyrite, pyrite, magnetite, hematite and cassiterite-gold intergrowths (Fig. 3D). Sphalerite contains very low $\mathrm{Fe}, \mathrm{Cu}$ and $\mathrm{Cd}$ concentrations, never exceeding $1.0 \mathrm{wt}$. \%.

Gold I/ is associated with the main sulphides and has 2 different textural characteristics, which will be discussed in the next chapter.

Stage 3 in both deposits comprises sulphosalt mineralization, but with different compositions.

In Govezhda deposit the chemical characteristic of this stage is $\mathrm{Cu}, \mathrm{Pb}, \mathrm{Ag}, \mathrm{Sb}$.

It occurs in nests, discordant veinlets or replacements of earlier minerals. During this stage tetrahedrite, boulangerite, bournonite, pyrargyrite, proustite, owyheeite and cubanite have been deposited in micro-fractures mainly in sphalerite and galena (Fig. 2B).

In Svishti Plaz deposit the stage is characterized by $\mathrm{Cu}, \mathrm{Pb}, \mathrm{Ag}$ and $\mathrm{Bi}$ and has complex mineral composition. It occurs in discordant veinlets or more complex occurrences. The bismuth minerals and chalcopyrite are neither cut nor replaced by later minerals. 
According to textural relationships, relative succession among the Bi-minerals is established. Three sub-associations can be divided:

The earliest sub-assuciation comprises native $\mathrm{Bi}$, chalcopyrite, $\mathrm{Cu}-\mathrm{Pb}-\mathrm{Bi}$ sulfosalts and member from the bismuthinite-pekoite mineral series. All they form myrmecitic intergrowths with the size of the different minerals less than $10 \mu \mathrm{m}$ (Fig. 2C).

The second sub-association includes minerals with aikinite-friedrichite compositions. They are deposited as 10 to $30 \mu \mathrm{m}$ wide rims on the myrmecitic intergrowths. In BSE they look homogeneous (Fig. 2C).
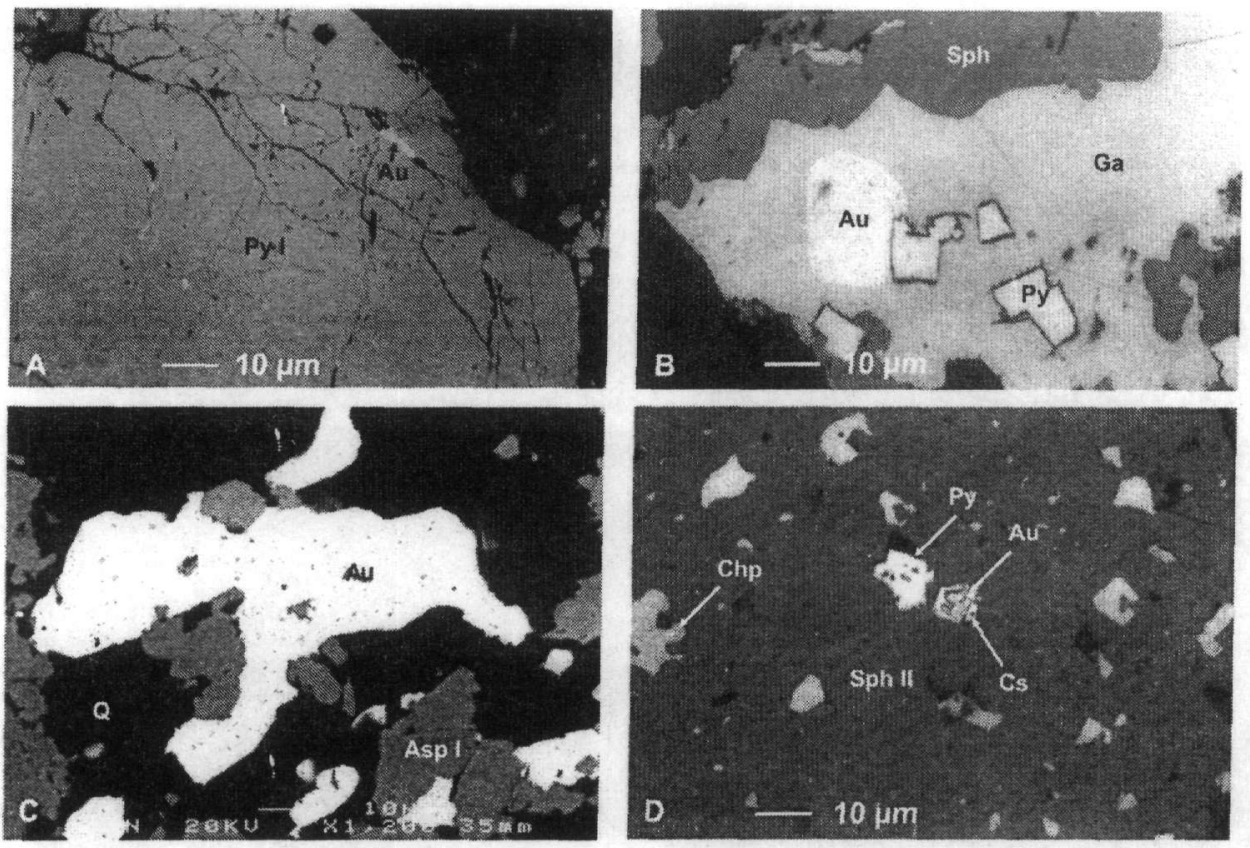

Figure 3. Native gold and its associations. A - Massive pyrite (Py) from stage 1 ( $F e-A s-A u \pm W$ ). The native gold (Au) is placed in microfractures in pyrite. Sample Svishti Plaz g6/2, B - Native gold (Au) with almost isometric shapes and isometric pyrite (Py) in galena and sphalerite ( $\mathrm{Sph}$ ) from the stage 2 ( $\mathrm{Pb}-\mathrm{Zn}$-Cu-Ag-Au), Sample Govezhda 610/23a, C - Native gold ( $A u$ ) embraces arsenopyrite crystals (Asp), the gangue is quartz (Q), SEM, BSE, Sample Svishti Plaz G6/5, D - Sphalerite from stage 2 ( $\mathrm{Pb}-\mathrm{Zn}$-Cu-Ag-Au) with chalcopyrite blebs and inclusions of pyrite, cassiterite and native gold. Sample Govezhda 610/23a

The bismuthiferous galena with exsolved acicular phases of berryite and benjaminite(?) composition is deposited last in the succession (Fig. 2D). It embraces the earlier bismuth minerals.

The pyrite from this stage is zonal, with solid central part and porous periphery, probably as a result of skeletal growth or replacement. Some parts of the crystals show strong tarnishing few days after polishing. Microprobe analyses of unaltered parts established high Co content, up to 4.52 wt $\%$. It is likely that the cobalt enrichment is due to later fluids, affecting pyrite and replacing some parts of it. The observations in BSE and microprobe analyses reveal that this pyrite includes small needlelike crystals of Bi-containing sulfosalts.

Based on spatial and geochemical proximity, we would suggest the Sredna Gora ore-forming solutions as possible source of the bismuthiferous mineralization in Svishti Plaz deposit. Probably some of the faults, hosting the Bi-mineralization in Svishti Plaz deposit were open during the Upper Cretaceous events, thus enabling the Sredna Gora ore-forming fluids to reach far from the place of their origin. The complex $\mathrm{Cu}-\mathrm{Pb}-\mathrm{Ag}-\mathrm{Bi}$ mineralization in Svishti Plaz seems to be a result of superimposition of late bismuthiferous solutions on the earlier minerals, causing reheating and remobilization of elements $(\mathrm{Pb})$ already present in the earlier minerals (Mladenova et al., 2001).

Stage $4(\mathrm{Fe})$ has a very simple mineral composition. The only ore mineral is hematite and gray quartz as gangue. This stage is abundantly presented only in Svishti Plaz deposit. Its occurrence is 
an evidence for opening of the vein system and increasing of $\mathrm{fO}_{2}$ in Svishti Plaz at the end of the ore deposition, which caused hydrothermal oxidation of earlier sulfides. In Govezhda deposit hematite is scarce and is observed as single grains in sphalerite (Fig. 3D).

Stage $\mathbf{5}(\mathrm{Ca}-\mathrm{Ba})$ is characterized by white calcite and milky barite, filling vugs and fractures in earlier minerals. Small breccias of earlier vein material are often enclosed in the carbonates, indicating that yet another fracturing took place prior to the late carbonate phase.

Detailed mineralogical description of the Bulgarian Paleozoic gold deposits is made by Mladenova, Kerestedjian (2002) and Mladenova et al. (2001; 2003).

We have insufficient data concerning the mineral successions of Serbian deposits. Compared to Bulgarian deposits, in the Serbian deposits arsenopyrite is very scarce, but scheelite is a main mineral there instead (Jankovic, 1982).

\section{THE GOLD AND THE PROCESS OF ITS DEPOSITION}

The economically important mineral in all deposits is the native gold, with variable $\mathrm{Ag}$ contents.

The textural features and chemical composition of the gold from the Bulgarian deposits point at its deposition in two stages of mineralization.

The gold from stage $1(\mathrm{Fe}-\mathrm{As}-\mathrm{Au} \pm \mathrm{W})$ is deposited in microscopic veinlets and voids in arsenopyrite and pyrite $\mathrm{I}$. This gold is located only inside the grains of these host minerals, alone or with some minerals from the stage 2, usually galena, tetrahedrite and sphalerite (Fig. 2A, 3D). This occurrence is the most $\varepsilon$ bundant one in the deposits.

In the deposits were arsenopyrite and pyrite are the main minerals, the visible gold precipitation is explained experimentally to be a result from electrochemical reactions on their mineral surfaces (Möller, 1994; 1995; Möller, Kersten, 1994).

In many deposits invisible gold is positively correlated with excess of arsenic in arsenopyrite (Cathelineau et al., 1989; Wu et al., 1990; Cook, Chryssoulis, 1990; Oberthür et al., 1997; Ashley et al., 2000). The main sulfide in both Bulgarian deposit is S-rich arsenopyrite with As:S ratio from 0.74 to 0.99 (Fig. 5) and in this case arsenopyrite is an n-semiconductor with a negative surfacecharge (Möller, Kersten, 1994). Nevertheless, in the investigated Bulgarian deposits, arsenopyrite fractures very often con ain microveinlets with native gold. Obviously the proposed model of Möller, Kersten (1994) is not applicable and the gold deposition is controlled by otiver factors.

Special analytical conditions were tried in the EPMA laboratory of the Bristol University (EUGF project), to detect possible "invisible gold" by spot microprobe analysis in 6 samples of arsenopyrite from Bulgarian deposits. The detection limit obtained was $37 \mathrm{ppm}$ at $95 \%$ confidentiality level. The analyzed samples did not show any gold within the mentioned detection limits.

The gold in the stage 2 ( $\mathrm{Pb}-\mathrm{Zn}-\mathrm{Cu}-\mathrm{Ag}-\mathrm{Au}$ ) has two associations.

The first one is represented by gold grains up to $100 \mu \mathrm{m}$. This gold is deposited simultaneously with the sulfides and the quartz of the stage. In this case the gold forms subhedral to euhedral grains and its depositior is related to a filling process (Fig. 3B, 3C). This type of gold is established in both the deposits.

The second one is established only in Govezhda deposit. The gold occurs within sphalerite, intimately intergrown with cassiterite and reaches up to several $\mu \mathrm{m}$ in size (Fig. 3D).

The electron microprobe analyses revealed that the gold from the Bulgarian deposits shows no significant differences depending on mineral associations (Table 1). It always shows silver contents ranging from 17.76 to 31.73 wt. \% in Svishti Plaz and from 13.90 to 25.14 wt. \% in Govezhda deposit. Generally, the native gold in the Govezhda deposit contains less Ag, while some samples from Svishti Plaz can clearly be classified as electrum (Fig. 4). In both deposits the native Au contains Cu below $1 \%$.

Based on mineral associations, three possible genetic concepts for gold deposition could be expressed.

a. The gold is genetically related to arsenopyrite and pyrite from stage 1 . It is primarily deposited as invisible gold in these minerals. During the next stage of sulfide deposition, driven by induced heating, it is remobilized and redeposited in cracks, formed during the cataclastic events of this stage. Such a mechanism of gold precipitation is proposed by Mumin et al. (1994) for the gold in Bogosu-Prestea mining district of the Ashanti Gold Belt, Ghana. Probably most of the gold in the 
Bulgarian deposits was initially precipitated as invisible gold in arsenopyrite and pyrite. Most or all of it was later remobilized and reprecipitated with the sulfides from the second stage.

Table 1. Chemical composition of native gold (in wt. \%) from the Bulgarian deposits (G - Govezhda; SvPI Svishti Plaz). Abbreviation: of mineral names - Au - gold; Ga - galena; Sph - sphalerite; Py - pyrite; Aspy arsenopyrite; $Q$ - quartz

\begin{tabular}{|c|c|c|c|c|c|c|c|c|}
\hline Sample & Mineral association (number of analyses) & $\mathrm{Au}$ & $\mathrm{Ag}$ & $\mathrm{Cu}$ & $\mathrm{Fe}$ & $\mathrm{Te}$ & As & Total \\
\hline G601/23a & idiomorphic Au in Ga \& Sph, (5) & 84.71 & 14.69 & 0.36 & & & & 99.76 \\
\hline $\mathrm{G} 601 / 23 a$ & $\mathrm{Au}$ in $\mathrm{Sph}$ as intergrowth with $\mathrm{SnO}_{2}$ (2) & 83.82 & 14.88 & 0.35 & & & 0.96 & 99.54 \\
\hline $\mathrm{Gg} 3 / 7$ & Au veinlet in $\mathrm{Py}(8)$ & 80.65 & 18.19 & 0.45 & 0.39 & & & 99.68 \\
\hline SvPI-6G/5 & in $Q$, embraces Aspy (6) & 78.66 & 18.87 & 0.54 & 0.59 & 0.22 & 0.71 & 99.66 \\
\hline SvPI-g.6/2 & pure Au veinlet in $\mathrm{Py}(3)$ & 70.21 & 28.09 & 0.99 & 0.47 & & & 99.86 \\
\hline SvPI - Tr. 7 & veinlet in $P_{j}^{\prime}(1)$ & 66.84 & 31.43 & 0.71 & 0.55 & & 0.22 & 99.75 \\
\hline
\end{tabular}

b. The gold is genetically related to the stage 2 . The reason why it is found in arsenopyrite and pyrite preferably is their strong fracturing enabling the infilling processes.

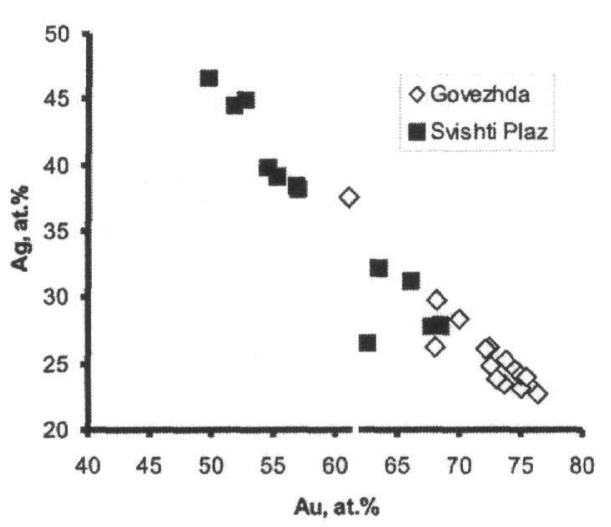

Figure 4. Correlation between $\mathrm{Au}$ and $\mathrm{Ag}$ (in at. \%) in native gold from the Bulgarian deposit

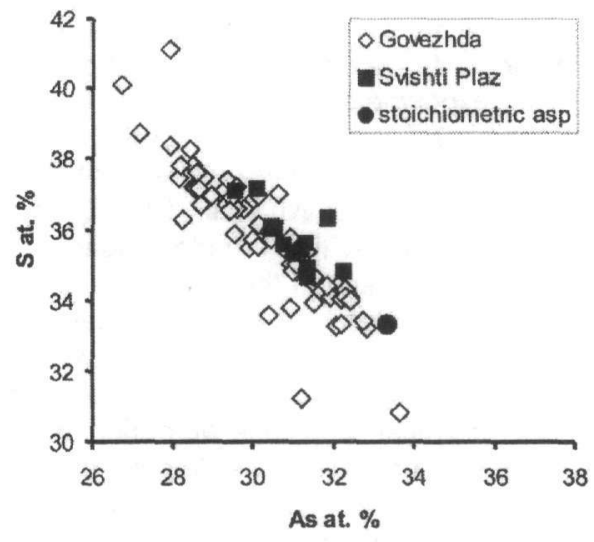

Figure 5. Correlation between As and $\mathrm{S}$ (in at. \%) in arsenopyrite from the Bulgarian deposit. The solid circle represents the stoichiometric composition

c. Dual generation of gold related to both stages 1 and 2 can not be excluded, but we can not provide unquestionable argumentation for a clear separation of two generations.

\section{GENETICAL REMARKS}

The granitoide magmatic bodies in Balkan Mountain are considered as source of gold ore deposition.

Amov et al. (1981) date the Paleozoic granitoids and ore mineralizations in the Western and Central Balkan Mountai and conclude that the gold mineralization in Govezhda and Svishti Plaz deposits have different ages and are connected to different types of granitoids. The age of 270-285 $\mathrm{Ma}$ (Permian) based on $\mathrm{Pb}$ isotopes in galena from Svishti Plaz is interpreted as a genetic relationship and a common endogenous source of hydrothermal mineralization and granite magmatism in the region. A later article connects the mineralization of Svishti Plaz deposit with Upper Cretaceous dyke magmatism without any data support (Cheshitev et al., 1995). Kamenov et al. (2002) provided new isotopic data for the Vezhen pluton using $\mathrm{U}-\mathrm{Pb}$ single zircon method and determined crystalli- 
zation age of the granodiorites at $314 \mathrm{Ma}$, e.g. Late Carboniferous age. They supposed involvement of mafic mantle magma in the evolution of the Vezhen granitoids according to isotopegeochemical $\mathrm{Rb} / \mathrm{Sr}$-whole rock and Hf-zircon tracing. It is most likely that Upper Cretaceous events have influenced on the mineralization in Svishti Plaz deposit and the superposition of the Sredna Gora bismuthiferous ore-forming solutions on the earlier Svishti Plaz one. This process involving possible reheating and iemobilization of elements $(\mathrm{Pb})$ already present in the earlier minerals, has resulted in the formation of the complex $\mathrm{Cu}-\mathrm{Pb}-\mathrm{Ag}-\mathrm{Bi}$ assemblage (Mladeriova et al., 2001).

An age of $360 \mathrm{Ma}$ (Middle Devonian) is accepted for the ore deposition in Govezhda deposit.

These results show that the Balkan Paleozoic gold deposits have still to be studied. Some of the genetic interpretations are only assumptions and need accurate scientific support. Precise geothermometric and isotopic data on distinct magmatic, mineralizing and metasomatic events should give a whole picture of the processes in the region of Balkan Mountain.

\section{COMPARISON WITH THE WORLDWIDE GOLD DEPOSIT IN METAMORPHIC TERRAINS}

All Balkan Paleozoic gold deposits show lots of similarities to mesothermal gold deposits in shear zones in Archaean greenschist terrains in Canada, Western Australia, Ghana and Zimbabwe, which were introduced during a period of multi-phase deformation, magmatism and metamorphism marking the final stabilization of the Archaean crust (Foster, 1990; Cassidy et al., 1998; Groves et al., 1998; Oberthür et al., 2000) where the gold mineralizations are specifically related to a late britthe event superimposed on early ductile shearing (Robert, Brown, 1986; Mueller et al., 1988). The gold-bearing hydrothermal activity generally postdates peak metamorphism and at least one phase of granitoide magmatisn, (Marmont, Corfu, 1989).

Similar complex tectonic events are recorded in Europe from the Hercynian orogeny of northern and northwestern part of Massif Central, France (Bouchot et al, 1989; Touray et al., 1989).

The similarities to Balkan deposits especially concern their connection to granodiorite magmatism, tectonic control and tectonic activity during the ore deposition, main ore minerals and succession of deposition, the gold occurrence and its associations. The main characteristic of the Balkan Paleozoic gold deposits are summarized in Table 2.

Unfortunately, the insufficient knowledge for the Pre-Alpine development of the Balkan zone for the moment prohibits an explicit attribution of the Balkan Paleozoic gold mineralizations to this structural type.

Table 2. Main characteristics of the Paleozoic Balkan gold deposits

\begin{tabular}{|c|c|c|c|c|}
\hline Deposit & Host rocks & Ore bodies & Mineral parageneses & Alteration \\
\hline $\begin{array}{l}\text { GOVEZHDA } \\
\text { (Bulgaria) }\end{array}$ & $\begin{array}{l}\text { diabase-fillitoid } \\
\text { complex }\end{array}$ & veins, lenses & $\begin{array}{l}\text { Ore: pyrite, arsenopyrite, gold, } \\
\text { chalcopyrite, galena, } \\
\text { sphalerite, scheelite } \\
\text { Gangue: quartz, calcite, }\end{array}$ & $\begin{array}{l}\text { argillization, silica- } \\
\text { tion, seritization, } \\
\text { carbonitization, pyri- } \\
\text { tization. }\end{array}$ \\
\hline $\begin{array}{l}\text { SVISHTI PLAZ } \\
\text { (Bulgaria) }\end{array}$ & $\begin{array}{l}\text { diabase-fillitoid } \\
\text { complex }\end{array}$ & veins, lenses & $\begin{array}{l}\text { Ore: pyrite, arsenopyrite, gold } \\
\text { chalcopyrite, galena, } \\
\text { sphalerite } \\
\text { Gangue: quartz, calcite, barite }\end{array}$ & $\begin{array}{l}\text { seritization, chloriti- } \\
\text { zation, } \\
\text { kaolinitization, sili- } \\
\text { cation }\end{array}$ \\
\hline $\begin{array}{l}\text { NERESNITZA } \\
\text { (Serbia) }\end{array}$ & chlorite schists & veins, lenses & $\begin{array}{l}\text { Ore: gold, pyrite, scheelite, } \\
\text { sphalerite galena, pyrargyrite } \\
\text { Gangue: quartz }\end{array}$ & No data \\
\hline $\begin{array}{l}\text { BLAGOEV- } \\
\text { KAMEN } \\
\text { (Serbia) }\end{array}$ & $\begin{array}{l}\text { contact zone be- } \\
\text { tween granite and } \\
\text { schists }\end{array}$ & $\begin{array}{l}\text { veins, me- } \\
\text { tasomatic } \\
\text { bodies }\end{array}$ & $\begin{array}{l}\text { Ore: gold, scheelite, pyrite, } \\
\text { sphalerite galena, pyrargyrite, } \\
\text { Gangue: quartz }\end{array}$ & No data \\
\hline $\begin{array}{l}\text { OSANITZA } \\
\text { (Serbia) }\end{array}$ & $\begin{array}{l}\text { contact } z c \text { ne be- } \\
\text { tween granite and } \\
\text { gneisses }\end{array}$ & veins & $\begin{array}{l}\text { Ore: wolframite, stibnite, py- } \\
\text { rite, marcasite, scheelite, gcld } \\
\text { Gangue: quartz }\end{array}$ & No data \\
\hline
\end{tabular}




\section{CONCLUSIONS}

Despite that the mining in the Balkan gold deposits is already closed, they still have nonexplored and non-operated reserves. On the other hand the oxidation of sulfides in mining environments gives rise to significant environmental problems regarding the acid drainage it induces and the release of potentially toxic elements (Alpers et al., 1994; Jambor et al., 2000).

These deposits hav ? still to be studied. Precise alteration, thermometric and isotopic studies should give a whole picture of the mineralizing process.

With the development of modern technologies for gold extraction from As-rich ores and the solution of the ecological problems, these deposits will represent an interest in the future because of their high Au contents.

Acknowledgements: The authors gratefully acknowledge Mr. Christo Stanchev (Laboratory Eurotest, Sofia) for providing microprobe analyses. Special thanks are due to Dr. Stuart Kearns (EPMA laboratory, Bristol University) who provided the specialized EPMA investigation of minor Au contents in arsenopyrite as part of an EUGF project.

This study was supported financially by the National Foundation for Scientific research, grant $710 / 1997$.

\section{REFERENCES}

Alpers, C. N., Blowes, D. W., Nordstrom, D. K., and Jambor, J. L., 1994. Secondary minerals and acid mine water chemistry, In: The environmental geochemistry of sulfide mine-wastes, Mineralog. Assoc. Canada, Short Course Handbook, 22, 247-270.

Amov, B., Arnaudov, V., Piıvlova, M., Dragov, P., Baldjieva, T., and Evstatieva, S., 1981. Lead isotope data on the Paleozoic granitoids and ore mineralizations from the Western Balkan Mountains and the Tran District (West Bulgaria). I. Isotopic ratios and geochronology, Geol. Balc., 11, 2, 3-26.

Ashley, P. M., Creagh, C. J., and Ryan, C. G., 2000. Invisible gold in ore and mineral concentrates from the Hillgrove gold-antimony deposits, NSW Australia, Mineral. Deposita, 35, 285-301.

Bouchot, V., Gros, Y., and Bonnemaison, M., 1989. Structural controls on the auriferous shear zones of the Saint Yrieix District, Massif Central, France: evidence from the Le Bourneix and Laurieras Gold deposit, Econ. Geol., 84, 1315-1327.

Cathelineau, M., Boiron, M-C., Holliger, P., Marion, P., and Denis, M., 1989. Gold in arsenopyrites: crystal chemistry, location and state, physical and chemical condition of deposition, Econ. Geol., Monogr. 6, 328341.

Cassidy, K. F., Groves, D. I., and McNaughton, N. J. 1998. Late-Archean granitoid-hosted lode-gold deposits, Yilgarn Craton, Western Australia: deposit characteristic, crustal architecture and implications for ore genesis, Ore Geol. Rev., 13, 65-102.

Cheshitev, G., Milanova, V., Sapunov, I., and Tchoumatchenco. P., 1995. Explanatory note to the geological map of Bulgaria on scale 1:100000, Teteven map sheet, 94 p., (in Bulgarian).

Cook, N. J., and Chryssoulis, S. L., 1990. Concentrations of "invisible gold" in the common sulfides, Can. Mineral., 28, 1-16.

Foster, R. P., 1990. Gold mineralization: recent advances in predictive metallogeny, Terra Review, 215-225.

Groves, D. I., Goldfarb, R. J., Gebre-Mariam, M., Hagemann, S. G., and Robert, F., 1998. Orogenic gold deposits, a proposed classific ation in the context of their crustal distribution and relationship to other gold deposit types, Ore Geol. Rev., 13, 7-27.

Haydoutov, I., 1991. The Thracian Hercynian suture and the related magmatism, Geotect., Tectonophys. and Geodynam., 23, 3-25 (in Bulgarian).

Ivanov, J., 2002. Tectonics of Bulgaria, Sofia University Press, (in press).

Ivanov, Z., Kolceva, K., Moskovski, St., and Dimov, D., 1987. Des particularites et du caractere de la "formation diabaso-phyllitoide", Rev. Bul. Geol. Soc., 48, 2, 1-24 (in Bulgarian).

Jambor, J. L., Blowes, D. W., and Ptacek, C. J., 2000. Mineralogy of mine wastes and strategies for remediation, In: EMU Notes in Mineralogy, 2, Ch. 7, 255-290.

Jankovic, S., 1982. Yugoslavia, In: Dunnina et al. Eds., Mineral deposits of Europe, 1982, 2, 406pp.

Kalaidjiev, S., Stoyanov, S., Tzvetkov, T., and Stoyanov, I., 1989. New data on the distribution of hydrothermal mineralizations in Govejda ore field, In: Geology and Ore Deposits of North-West Bulgaria, Sofia, Technika, 108-114 (in Bulgarian).

Kamenov, B. K., Quadt, A. v, and Peytcheva, J., 2002. New insight into petrology, geochemistry and dating of the Vejen pluton, Bulgaria, Geochem., Mineral. Petrol., 39, 3-25. 
Kujkin, S. S., and Milanov, L. B., 1970. Über dem Geologischenbau von einem Teil der Zlatishka Stara planina, Rev. Bulg. Geol. Soc., 31, 1, 120-126 (in Bulgarian).

Kuikin, S., Staikova, M., and Hristov, S. 1972. Über die Gold-Sulfid Vererzung in Zlatica-Balkan, Bull. Geol. Inst., 21, 55-68 (in Bulgarian).

Marmont, S., and Corfu, F., 1989. Timing of gold introduction in the late Archaean tectonic framework of the Canadian Shield: Evidence from U-Pb Zircon Geochronology of the Abitibi Subprovince, Econ. Geol. Monogr., 6, 101-111.

Milev, V., Stanev, V., and I ranov, V., 1996. The mined ore in Bulgaria in the period 1878-1995, Statistical reference book, Sofia, Zemja, 196pp, (in Bulgarian).

Mladenova, V., and Kerestedjian, T., 2002. The Svishti Plaz gold deposit, Centrai Balkan Mountain, Bulgaria, Geochem. Mineral. Petrol., 39, 53-65.

Mladenova, V., Kerestedjian, T., and Dimitrova D., 2001. Ag-Cu-Pb-Bi mineralization from the Svishti Plaz gold deposit, Central Balkan Mountain, Bulgaria, Geochem., Mineral. Petrol., 38, 55-66.

Mladenova, V., Kerestedjian, T., and Dimitrova, D., 2003. The Govezhda gold deposit, Western Balkan Mountains, Bulgaria, Geochem. Mineral. Petrol., 40, 109-121.

Möller, P., 1994. Accumulation of gold on natural sulfides: the electrochemical function of arsenic in nature, Geol. Jb., D100, 639-660.

Möller, P., 1995. Accumu ation of gold by electrochemical processes, In: Prehistorical gold in Europe, G. Morteani \& J. P. Northover (eds.), 145-157.

Möller, P., and Kersten, G., 1994. Electrochemical accumulation of visible gold on pyrite and arsenopyrite surfaces, Miner. Deposita, 29, 404-413.

Mueller, A. G., Harris, L. B., and Lungan, A., 1988. Structural control of greenstone-hosted gold mineralization by transcurrent shearing: a new interpretation of the Kalgoorlie Mining District, Western Australia, Ore Geol. Rev., 3, 359-387.

Mumin, A. H., Fleet, M. E., and Chryssoulis, S. L., 1994. Gold mineralization in As-rich mesothermal gold ores of the Bogosu-Prestea mining district of the Ashanti Gold Belt, Ghana: Remobilization of "invisible" gold, Mineral. Deposita, 29, 445-460.

Nikolaev, G., Tonev, I., 19E1. Geological setting of vicinity of Kopilovci village and the mineralization of the goldquartz-sulfide veins, Ann. Univ. Mining Geol., Sofia, 7, 2, 23-36 (in Bulgarian).

Oberthür, T., Blenkinsop, T. G., Hein, U. F., Höppner, M., Höhndorf, A., and Weiser, T. W., 2000. Gold mineralization in the Mazowe area, Harare-Bindura-Shamva greenstone belt, Zimbabwe: II. Genetic relationships deduced from mineralogical, fluid inclusion and stable isotope studies, and the $\mathrm{Sm}-\mathrm{Nd}$ isotopic composition of scheelites, Mineral. Deposita, 35, 138-156.

Oberthür, T., Weiser, T., Amanor, J. A., and Chryssoulis, S. L., 1997. Mineralogical sitting and distribution of gold in quartz veins and sulfide ores of the Ashanti mine and other deposits in the Ashanti mine and other deposits in the Ashanti belt of Ghana: genetic implications, Mineral. Deposita, 32, 2-15.

Parvanov, I., and Mateev, S., 1980. Report on exploration results of Svishti Plaz gold deposit in 1975-1979 with mineral reserves calcul ation, Unpubl., National Geofund, (in Bulgarian).

Petrov, H., 1981. Report on the exploration in 1974-1980 in Brezov Rat, Cherna Reka, Izvora and Debeli Rat subsections of the Central part of the Govezhda gold deposit, Mihaylovgrad district, Geofund Comm. Geol., Unpubl., I-1030 (in Bulgarian).

Robert, F., and Brown, A. C., 1986. Archean gold-bearing quartz veins at the Sigma mine, Abitibi greenstone belt, Quebec: Part I. Geologic relations and formation of the vein system, Econ. Geol., 81, 578-592.

Touray, J.-C., Marcoux, E., Hubert, P., and Proust D., 1989. Hydrothermal processes and ore-forming fluids in the Le Bourneix gold deposit, Central France, Econ. Geol., 84, 1328-1339.

Wu, X., Delbove, F., and Touray, J. C., 1990. Condition of formation of gold bearing arsenopyrite: a comparison of synthetic crystals with samples from Le Chatelet gold deposit, Creuse, France, Mineral. Deposita, 25, 812. 